\title{
Charles E. May, ed., Critical Insights: Alice Munro
}

\section{Christine Lorre-Johnston}

\section{(2) OpenEdition}

1 Journals

Electronic version

URL: https://journals.openedition.org/ces/5719

DOI: 10.4000/ces.5719

ISSN: 2534-6695

\section{Publisher}

SEPC (Société d'études des pays du Commonwealth)

\section{Printed version}

Date of publication: 1 April 2015

Number of pages: 117-118

ISSN: 2270-0633

\section{Electronic reference}

Christine Lorre-Johnston, "Charles E. May, ed., Critical Insights: Alice Munro", Commonwealth Essays and Studies [Online], 37.2 | 2015, Online since 13 April 2021, connection on 17 July 2021. URL: http:// journals.openedition.org/ces/5719; DOl: https://doi.org/10.4000/ces.5719

This text was automatically generated on 17 July 2021.

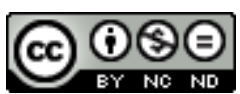

Commonwealth Essays and Studies is licensed under a Licence Creative Commons Attribution - Pas d'Utilisation Commerciale - Pas de Modification 4.0 International. 


\title{
Charles E. May, ed., Critical Insights: Alice Munro
}

\author{
Christine Lorre-Johnston
}

\section{REFERENCES}

Charles E. May, ed. Critical Insights: Alice Munro. Ipswich, MA: Salem P, 2013. 312 p. ISBN (hb): 9781429837224. \$95

1 Salem Press was originally founded by Frank N. Magill, who during his posting in the Panama zone in World War II imagined a publishing house devoted to the great works of literature, American and international, providing plot summaries to guide or refresh the memories of curious general readers. The "Critical Insights" series in which this book on Alice Munro's short fiction is published is the heir of the "Masterworks" series created by Magill, which has been successful with librarians and library patrons since the 1950s. The goal remains, as it first was, to reach a wide readership, ranging, as one can read on the publisher's website, from "the student approaching a subject for the first time, the reader trying to decide which book to read for pleasure, the teacher needing a quick reminder of a character's name in a book read many years ago, the graduate student reviewing for orals, the reference desk librarian needing to quickly answer a question for a patron." One question that comes to mind is whether the Critical Insights book on Munro will also interest a Munro scholar. My answer is yes, very much so, and this for several reasons.

2 The fact that the volume's editor is Charles E. May is a good omen. May has devoted his whole academic life to the genre of the short story and has produced an enduring body of theory and criticism. His Short Story Theories, first published in 1976, augmented to The New Short Story Theories in its 1994 edition, is a major reference. May has successfully met the challenge of addressing the broad readership of Salem Press, as the contributions to this volume include both essential information about Munro and several important essays. The book is structured into three parts, following a set 
pattern - "Career, Life, and Influence," "Critical Contexts," and "Critical Readings" reflecting the overall perspective of the books in the series.

Following the series editorial line, the volume focuses on Munro's "entire body of work" - that is, her thirteen original collections of short stories up to Too Much Happiness (2009), since Dear Life, her 2012 collection, and officially her last, was published after this book was conceived. Dealing with an "entire body of work" is problematic in the case of short stories, which are independent narrative units, and particularly so in the case of Munro's stories, due to their marked singularity. In reality this book's approach is comprehensive only to the extent that this is possible; it does not mean that all the stories are discussed, but most chapters in the book adopt an embracing approach to a given collection of stories, and not all of these are covered. An embracing approach here means that a general statement is made about a collection, and then a few sample stories are examined to illustrate that point.

The first section, "Career, Life, and Influence," comprises two pieces by May. "On Alice Munro" provides a survey of essential aspects of Munro's stories, such as the length of her narratives and their similarities and differences with the novel, the prevalence of the theme of the ordinary, or the universal value that the stories convey. "Biography of Alice Munro" surveys the author's life and how it shaped her writing. There is nothing new here for the Munro scholar, but May's two-fold survey is an excellent introduction to Munro's work.

"Critical Contexts" brings together four chapters. "Critical reception," by Robert Thacker, is not only a thoughtful, updated survey of Munro criticism (which Thacker has been consistently doing since criticism on Munro was first published), but also addresses the question of how to deal with Munro's work, and the relevance of an "overall approach." Thacker's view is that "Munro's art [...] is not well served by the critical form of the single-author extended critical overview," and that "her work is best understood at the level of the single story or by considering a small group of stories" $(34,35)$. This amounts to setting a challenge to the contributors to the book, given the book's editorial perspective, but it also feeds into the reflection of Munro scholars. Timothy McIntyre's article focuses on the links between Munro's biography and writing, in terms well-known to seasoned Munro readers. Naomi Morgenstern's piece uses a psychoanalytical approach to read "Trespasses" and "Deep-Holes," which leaves us to wonder about the potential and limits of this specific theoretical perspective. Carol L. Beran's parallel reading of Munro's "White Dump" and Atwood's "Wilderness Tips" is spurred by her interest in the two of them being Canadian women writers - this is familiar but important critical ground.

6 The "Critical Readings" section offers a range of articles that go from thematic summary (David Peck's chapter on theatricality in The Beggar Maid), to analysis of important themes that have been surveyed extensively by scholarship (Michael Toolan on secrets in Open Secrets), to strong argument about emerging questions - so Ailsa Cox examining Munro's "Late Style" in Too Much Happiness, detailing how "the continuity between past and present is undermined by the brutality with which one time frame supersedes another" (279). Most articles offer insightful perspectives that expand on important questions. Medrie Purham's "Lives of Girls and Women and the Classical Past" offers a cogent argument about cultural background in Munro's most famous book. Mark Levene examines "the compound, layered endings" of several stories from The Progress of Love. Philip Coleman focuses on Friend of My Youth to show, by establishing 
links with modernist writers (Joyce, Woolf), how Munro's short fiction "reveals the pervasiveness of stories and the processes of [what Susan Lohafer has called] storying in all areas of subjective and intersubjective experience" (173). J. R. (Tim) Struthers, through a study of "Meneseteung," compellingly examines the role metaphor plays for us as readers, "for orienting ourselves" (190). Jeff Birkenstein studies the meaning of community in The Love of a Good Woman. David Crouse proposes the notion of "surrogate authors" to analyse the way "Munro's characters are always telling themselves tales and telling other people lies" (229) in Hateship, Friendship, Courtship, Loveship, Marriage. Michael Trussler deals with "Narrative, Memory, and Contingency" in Runaway, raising the crucial notion of connectedness and the way characters experience temporality. Caitlin Charman studies "Place Sense" in The View from Castle Rock, in terms of how landscape is read, how place is understood.

7 Following Thacker's opening article, which sets the critical tone of the volume, the strongest articles in the book expand our reading of the individual stories by raising questions about the links between life and writing, and interrogating the role of literature, culture, and personal background. How does classical culture shape Munro's outlook? What matters to readers and writers of short stories? How has age changed Munro's writing? This is the kind of essential questions that Salem Press traditionally wishes to address. And these are questions that scholars too, especially if they want to bear the equivalent of a Woolfian "common reader" in mind, should not lose sight of.

\section{AUTHORS}

\section{CHRISTINE LORRE-JOHNSTON}

Christine LORRE-JOHNSTON is a Senior Lecturer in English at University Sorbonne Nouvelle. Her research and writing focus on the short story, the literature of the Asian diaspora, postcolonial theory, gender and cultural studies. Her publications include an issue of Commonwealth Essays and Studies on "Janet Frame: Short Fiction" (co-edited with Marta Dvorak, Spring 2011) and a study of Munro's Dance of the Happy Shades entitled The Mind's Eye (co-authored with Ailsa Cox, Fahrenheit, 2015). 